\title{
License Procurement and the Federal Mail Fraud Statute
}

\author{
Donna M. Maus†
}

An applicant for a city taxi driver's license cheats on a test on local geography. An individual misrepresents the ownership of a business establishment to obtain a state liquor license. A student forges an academic transcript in order to obtain a state license to practice medicine. An arms dealer conceals an intent to sell arms to Iraq in order to obtain an arms export license from the federal government. Activities such as these, involving deceit and material misrepresentations and omissions, constitute fraud under the common law and under many state statutes. Some prosecutors assert, however, that these acts also constitute mail fraud under 18 USC $\S 1341$. The breadth of $\S 1341$ has fluctuated over the last several years, leaving uncertainty as to whether any or all of the above activities constitute mail fraud. Because $\S 1341$ now requires that "money or property" be the object of the fraud, the crucial inquiry examined by this Comment is whether licenses are "property" for purposes of the statute.

Section I examines the Supreme Court case law on, and recent congressional changes to, the mail fraud statute and outlines the various approaches the lower courts have taken in determining whether schemes like those described above involve money or property. Section II explains the "money or property" requirement, concluding that a cognizable offense under $\S 1341$ requires both that a victim lost or stood to lose valuable property, and that the schemer gained or stood to gain property. The property at issue may be either tangible or intangible, provided that it is of some material value to the victim. Section III applies the "money or property" requirement to cases involving fraudulently obtained licenses, permits, and professional certificates, borrowing heavily from definitions of property developed by courts in other contexts. Section III also examines the somewhat slippery distinction between property that a government holds and property that a govChicago.

† B.B.A. 1986, University of Notre Dame; J.D. Candidate 1992, The University of 
ernment merely regulates. The Comment concludes that none of the activities described above constitutes mail fraud unless the defendant corrupts government officials in the process of obtaining the license. In these cases, the schemer defrauds the issuing agent of its rights as a regulator, not its rights as a property holder, and thus does not take money or property.

\section{The Judicial Introduction of the "Money or Property" Requirement and the Congressional Response}

In the last four years, both the Supreme Court and Congress have redefined the contours of the federal offense of mail fraud. The Supreme Court's landmark decision in McNally $v$ United States, ${ }^{1}$ which held that $\S 1341$ protects only victims' money and property rights, represented a sharp break from the historically expansive reading of $\S 1341$. Congress reacted by partially overruling McNally by statute. ${ }^{2}$ In those cases decided before Congress took action, and in those cases that Congress's mail fraud amendment does not reach, the lower courts have found ways to avoid the $\mathrm{Mc}$ Nally restrictions.

\section{A. Historical Scope of the Mail Fraud Statute}

The mail fraud statute and its counterpart, the wire fraud statute ${ }^{3}$ historically have been powerful instruments for prosecutors. ${ }^{4}$ Section 1341 prohibits "any scheme or artifice to defraud, or for obtaining money or property by means of false or fraudulent pretenses or promises." Prosecutors have long been able to use this seemingly all-encompassing language both to supplement more specific fraud statutes ${ }^{5}$ and to prosecute those whose practices had not yet been specifically prohibited by the legislature. ${ }^{\circ}$ The courts

2483 US 350 (1987).

218 USC § 1346 (1988). See discussion in Section I.B.

s 18 USC \& 1343 (1988).

- See Jed S. Rakoff, The Federal Mail Fraud Statute (Part I), 18 Duquesne L Rev 771 (1980) (calling the mail fraud statute federal prosecutors" "true love"). See statistics cited in John C. Coffee, Jr., The Metastasis of Mail Fraud: The Continuing Story of the "Evolution" of a White Collar Crime, 21 Am Crim L Rev 1, 9 n 41 (1983).

s See, for example, United States v Green, 494 F2d 820 (5th Cir 1974) (prosecution under the mail fraud statute and the Truth in Lending Act); Sanders $v$ United States, 415 F2d 621 (5th Cir 1969) (prosecution under the mail fraud statute and the Securities Act of 1983).

- In United States v Maze, 414 US 395, 406 (1974) (Burger dissenting), for example, Chief Justice Burger noted that $\$ 1341$ was previously used to prosecute activities now prohibited in the Securities Act of 1933, 15 USC \& 77a et seq (1988) (fraudulent securities transactions); federal law regarding extortionate credit transactions, 18 USC $\S 891$ et seq 
have emphasized the word "any" in $\S 1341$ 's prohibition of "any scheme or artifice to defraud." Prosecutors did not need to show that the victim of the scheme was deprived of money, property, or any tangible right. A showing that "intangible rights" were violated sufficed. ${ }^{7}$

Historically, cases involving fraudulently procured licenses were rare and tended to involve the corrupt participation of a government official (thus affording prosecution under the intangible rights doctrine).$^{8}$ In only two recorded instances did courts allow the use of the mail fraud statute to convict a person who had employed fraud (but not the corruption of others) to obtain a license. ${ }^{9}$

As the mail fraud statute grew to cover more types of fraud, especially breaches of fiduciary duties under the "intangible rights" theory, so did criticism of its scope. Commentators and dissenting judges saw an unwarranted expansion of the mail fraud statute into areas for which it was never designed and feared its potential abuse. ${ }^{10}$ They cited particularly the lack of reasonable

(1988) (loansharking activities); the Interstate Land Sales Full Disclosure Act, 15 USC \& 1701 et seq (frauds in the sale of undeveloped real estate); and 15 USC $\$ 1644$ (1974) (credit card fraud).

${ }^{7}$ By 1987, every circuit had endorsed some form of this theory, although it was usually limited to cases involving fiduciary or contractual relationships. See United States $v$ Berg, 710 F Supp 438, 441 n 3 (E D NY 1989), rev'd on other grounds as United States $v$ Schwartz, 924 F2d 410 (2d Cir 1991), for a list of representative "intangible rights" cases.

- See United States v Haimowitz, 725 F2d 1561, 1567-71 (11th Cir 1984) (the defendant fraudulently sought to obtain a liquor license by enlisting the "aid" of a State Senator. The court upheld the conviction on the theory that the citizens had been deprived of their rights to the Senator's honest and faithful service and to "pertinent and true information" in the administration of the state's laws.); United States v Sedovic, 679 F2d 1233 (8th Cir 1982) (court upheld the conviction of a city auditor who had accepted bribes for conducting sham tax audits and distributing business licenses).

- In United States v Green, 577 F Supp 935, 936-37 (N D Cal 1984), a federal district court convicted a defendant who had obtained a driver's license under an assumed name, on the then novel theory that the defendant had used the mails "to defraud the United States of the right to bring defendant to justice, and to defraud the California Department of Motor Vehicles of its right to have its license program administered free from falsehood." Id at 937. In United States $v$ Castor, 558 F2d 379, 384 (7th Cir 1977), the Seventh Circuit upheld a conviction for a scheme in which the defendant fraudulently obtained liquor store permits by misrepresenting the applicants' identities, on the theory that the fraud diminished the other applicants' chances to obtain the permits and thus reduced their chances to make profits. For criticism of this theory, see note 101.

${ }^{10}$ See United States v Margiotta, 688 F2d 108, 143 (2d Cir 1982) (Winter dissenting) ("The limitless expansion of the mail fraud statute subjects virtually every active participant in the political process to potential criminal investigation and prosecution."); United States v Siegel, 717 F2d 9, 24 (2d Cir 1983) (Winter dissenting) (complaining that the majority used the wire fraud statute to create a "federal law of fiduciary obligations"); and Sedima S.P.R.L. v Imrex Co., 473 US 479, 502 (1985) (Marshall dissenting) (recognizing the "staggering" implications of "making a mere two instances of mail or wire fraud potentially 
forewarning of criminal acts ${ }^{11}$ and the potential for discriminatory prosecution. ${ }^{12}$

\section{B. McNally, Carpenter, and the Congressional Response}

The Supreme Court abolished the intangible rights theory in McNally $v$ United States by holding that $\S 1341$ protects only victims' money and property rights. ${ }^{13}$ Specifically, the Court held in McNally that a bribery scheme in which citizens were deprived only of an intangible right to the honest conduct of governmental affairs was not an offense under $\S 1341 .{ }^{14} \mathrm{McNally}$ also suggested in a footnote that when the government is the identified victim of the fraudulent scheme, the prosecution must demonstrate an actual or potential injury to the government's rights as a property holder. ${ }^{15}$ That is, the government must have more than a regulatory interest in the property in question. ${ }^{16}$

Six months after the McNally decision, the Court revisited the "money or property" requirement. In Carpenter $v$ United States, Justice White, the author of the Court's opinion in McNally, wrote for a unanimous Court that McNally's "property" requirement included intangible as well as tangible property. ${ }^{17}$ Thus, after Car-

actionable under civil RICO," given the "extraordinary expansion" of those crimes in the courts of appeals). See generally Rakoff, 18 Duquesne L Rev at 772-73 (cited in note 4); Donald V. Morano, The Mail-Fraud Statute: A Procrustean Bed, $14 \mathrm{~J}$ Marshall L Rev 45, 78-80 (1980).

"Morano, $14 \mathrm{~J}$ Marshall L Rev at 77 (cited in note 10); Francis A. Allen, The Erosion of Legality in American Criminal Justice: Some Latter Day Adventures of the Nulla Poena Principle, 29 Ariz L Rev 385, 410-11 (1987).

${ }_{12}$ Margiotta, 688 F2d at 143 (Winter dissenting) ("[W]hat profoundly troubles me is the potential for abuse through selective prosecution and the degree of raw political power the freeswinging club of mail fraud affords federal prosecutors."); Allen, 29 Ariz L Rev at 410-11 (cited in note 11).

${ }^{13}$ McNally, 483 US at 360 .

14 Id.

15 Id at 358-59 $\mathrm{n} 8$.

16 United States v Evans, 844 F2d 36, 39, 42 (2d Cir 1988), established this point from a reading of footnote 8 in McNally. In footnote 8, the Court distinguished $\$ 1341$ 's emphasis on "money or property" from 18 USC \& 371, under which interfering with or obstructing a broader class of "lawful governmental functions" through deceit or dishonesty is a federal offense. McNally, 483 US at 358-59 n 8. See also United States v Ferrara, 701 F Supp 39, 42 (E D NY 1988), aff'd without opinion, 868 F2d 1268 (2d Cir 1988). Importantly, the courts have not required that the government lack a regulatory interest. That is, if the government's interest in the object of the fraud is both that of a regulator and that of a property holder, the McNally test is satisfied.

${ }_{17}$ Carpenter v United States, 484 US 19, $25-27$ (1987). Specifically, the Court held in Carpenter that the Wall Street Journal's confidential business information, including its publication schedule and the contents of its "Heard on the Street" column, was property, albeit intangible property. 
penter, courts must distinguish intangible non-property rights from intangible property rights to determine whether a scheme violates § 1341 .

Congress acted almost immediately to lessen the impact of McNally. ${ }^{18}$ Representative Conyers and Senator Specter introduced similar bills in Congress to include within the statute's reach schemes to "defraud[] another ... of intangible rights of any kind whatsoever in any manner or for any purpose whatsoever ...."19 A second proposal, submitted by Representative Mfume, would have revived the intangible rights theory only in cases involving the corruption of public officials. ${ }^{20}$ Senator McConnell ${ }^{21}$ and Representative Michel ${ }^{22}$ introduced a third proposal, sponsored by the Justice Department, which, like the Mfume bill, focused solely on the corruption of public officials. ${ }^{23}$

On November 18, 1988, Congress enacted The Anti-Drug Abuse Act of 1988, which added $\S 1346$ to Title 18 of the United States Code. This section brought within the statute's reach any "scheme or artifice to deprive another of the intangible right of honest services." contain the broad definition of "defraud" of the Conyers/Specter bill (including "intangible rights of any kind whatsoever in any manner or for any purpose whatsoever"), nor was it limited to fraud by public officials.

18 For a contemporaneous analysis of the congressional response to $M c N a l l y$, see Note, The Mail Fraud Statute After McNally v. United States, 107 S. Ct. 2875 (1987): The Remains of the Intangible Rights Doctrine and its Proposed Congressional Restoration, 25 Am Crim L Rev 743 (1988).

10 HR 3089, 100th Cong, 1st Sess, in 133 Cong Rec E3242 (daily ed, August 4, 1987); and S 1898, 100th Cong, 1st Sess, in 133 Cong Rec S16,742 (daily ed, November 30, 1987).

20 Under the Mfume proposal,"defraud" would mean "the defrauding of the citizens of a body politic-(1) of their right to the conscientious, loyal, faithful, disinterested, and unbiased performance of official duties by a public official thereof; or (2) of their right to have the public business conducted honestly, impartially, free from bribery, corruption, bias, dishonesty, deceit, official misconduct, and fraud." Mail Fraud Amendment Act of 1987, HR 3050, 100th Cong, 1st Sess, in 133 Cong Rec H6802 (daily ed, July 29, 1987).

${ }_{21}$ The Anti-Public Corruption Act of 1988, S 2531, 100th Cong, 2d Sess, in 134 Cong Rec S8134, S8054 (daily ed, June 17, 1988).

${ }^{22}$ Subtitle $J$ of the Comprehensive Anti-Drug Abuse Act of 1988, HR 4842(J), 100th Cong, 2d Sess, in 134 Cong Rec H4427 (daily ed, June 16, 1988).

${ }^{23}$ The McConnell/Michel bill proposed making it a crime to endeavor "by any scheme or artifice corruptly to deprive or to defraud" the public "of the honest services of a public official or a person who has been selected to be a public official" at the federal level, or of any official employee of any state or subdivision. S 2531, in 134 Cong Rec S8134 (cited in note 21); H R 4842(J), in 134 Cong Rec H4427 (cited in note 22).

24 18 USC § 1346 (1988) (Added Pub L 100-690, Title VII, Subtitle O, § 7603(a), November $18,1988,102$ Stat 4508$)$. 
Since the adoption of $\S 1346$, most circuits have recognized that fraud under $\S 1341$ still requires a showing of money or property except in cases involving deprivations of the intangible right to honest services. ${ }^{25}$ That is, $\S 1346$ invalidates only the narrow holding of McNally. A minority have asserted that $\S 1346$ invalidates the broad holding of McNally, and that prosecutors need never show a threatened loss of money or property. ${ }^{26}$ This interpretation may well reflect the courts' antipathy toward the $\mathrm{Mc}$ Nally decision. ${ }^{27}$ These courts have often bolstered the language of the statute by referring to Representative Conyers's remarks in hearings before the House Subcommittee on Criminal Justice: "This amendment restores the mail fraud provision to where that provision was before the McNally decision.... Thus it is no longer necessary to determine whether or not the scheme or artifice to defraud involved money or property." 28

This interpretation of $\S 1346$ is incorrect. Section 1346 clearly defines one instance of fraudulent behavior: "scheme[s] or artifice[s] to deprive another of the intangible right of honest services." The statute goes no farther. Nor is the language of $\S 1346$ sufficiently unclear or ambiguous to warrant study of the statute's legislative history. ${ }^{29}$ Even should one regard it necessary to consult the legislative history, reliance on Conyers's statements is misplaced..$^{30}$ The Conyers/Specter proposal, which would have given back to $\S 1341$ its pre-McNally force and effect, was not enacted.

${ }^{25}$ See, for example, United States $v$ Shyres, 898 F2d 647, 651-52 (8th Cir 1990), cert denied, 111 S Ct 69 (1990); United States $v$ Granberry, 908 F2d 278, 280 (8th Cir 1990), cert denied, 1991 US Lexis 2643; United States v Martinez, 905 F2d 709, 715 (3d Cir 1990), cert denied, 111 S Ct 591 (1990).

${ }^{26}$ United States $v$ Little, 889 F2d 1367, 1369 (5th Cir 1989), cert denied, 110 S Ct 2176 (1990) ( $\$ 1346$ "effectively overrules McNally by eliminating the requirement of property loss"); Frank v United States, 914 F2d 828, 835 n 1 (7th Cir 1990) (Cudahy dissenting).

27 See, for example, Frank, 914 F2d at 835 (Cudahy dissenting) (sympathizing with the courts' "understandably strong reluctance to invalidate mail fraud convictions based on intangible rights deprivations").

${ }^{28} 134$ Cong Rec H11,251 (daily ed, October 21, 1988). At least one court has been persuaded that Conyers's statements reflect the sole, uncontradicted congressional intent in enacting $\S 1346$. Berg, 710 F Supp at 442 . See also Martinez, 905 F2d at 715.

${ }^{28}$ Moreover, legislative history should not be used to expand or contradict the plain meaning of a statute. United States $v$ Ron Pair Enterprises, Inc., $109 \mathrm{~S} \mathrm{Ct} \mathrm{1026,} 1031$ (1989).

${ }^{30}$ Conyers's fundamental concern was not the complete restoration of the intangible rights theory. Rather, Conyers was only pushing to keep public corruption and white-collar crime cases within the statute's purview. 133 Cong Rec E3240-42 (daily ed, August 4, 1987). His statement before the Subcommittee is in fact accurate with respect to these types of crimes. 
In cases involving fraudulently obtained licenses or permits, the prosecution must prove a fraud involving money or property. ${ }^{31}$

\section{C. "Finding" Property Where No Property Was Thought to Exist}

The courts have effectively circumvented McNally's "money or property" requirement by finding a wide variety of intangible rights to be property. Justice Stevens, in a strong dissent to $\mathrm{Mc}$ Nally, had actually encouraged this end-run around the majority's test. Specifically, he suggested how prosecutors in public corruption cases might re-cast intangible rights as lost property rights. ${ }^{32}$ Other creative property rights began appearing in post-McNally mail fraud indictments; many of these have been recognized by the courts. For example, after McNally, courts have recognized as property rights "the right to control spending of [one's] own funds," 33 "the right to pay for services alone, not services plus kickbacks,"34 "information relevant to [one's] economic welfare concerning the existence of [a] kickback scheme,"35 and the "economic value of . . . knowledge that [a] contractor would sell for less." 36

Most courts have determined that McNally is retroactive, thus affording persons who were convicted before McNally opportunities to collaterally attack their convictions. ${ }^{37}$ In addition, a number

ss Of course, if the defendant obtained the license or permit by bribing or corrupting public officials, or through any other scheme in which the citizenry was deprived of "honest services," $\$ 1346$ applies, and no loss of "money or property" need be alleged. The analysis in Section III of this Comment assumes frauds that do not involve the deprivation of honest services.

${ }^{32}$ McNally, 483 US at 377 n 10 (Stevens dissenting). Justice Stevens suggested first, that a breach of loyalty "carr[ies] with it some loss of money to the employer-who is not getting what he paid for," and second, that an employee who "receives anything as a result of his violation of a duty of loyalty" to the employer is subject to liability to deliver it to the employer under an "agency" theory. Id (citing Restatement (Second) of Agency § 403 (1958)). Several circuits subsequently endorsed Justice Stevens's "constructive trust" theory. See United States v Richerson, 833 F2d 1147, 1157 (5th Cir 1987); United States v Runnels, 833 F2d 1183, 1186 (6th Cir 1987).

33 Shyres, 898 F2d at 653.

${ }^{34}$ Id (citations omitted).

${ }^{35}$ Id (citations omitted).

36 Little, 889 F2d at 1368.

37 See, for example, United States v Allard, 864 F2d 248. (1st Cir 1989); United States $v$ Osser, 864 F2d 1056 (3d Cir 1988); United States v Mandel, 862 F2d 1067 (4th Cir 1988); Toulabi $v$ United States, 875 F2d 122 (7th Cir 1988). On direct appeal, a court will uphold a conviction cast solely in terms of intangible rights if the jury was explicitly required to base its conviction on conduct currently proscribed by the statute, United States v Ochs, 842 F2d 515, 523 (1st Cir 1988), or if it must have found a deprivation of money or property. Toulabi, 875 F2d at 123 . 
of mail fraud cases were pending direct appeal at the time $\mathrm{Mc}$ Nally was decided, forcing the courts of appeals to decide whether "improper intangible rights instructions so polluted the jury's deliberations as to render the conviction invalid ...." ${ }^{\prime 38}$ In reviewing the outcome of such appeals and collateral attacks, one judge has noted that some courts have "stretched to find more ingenious theories of property loss which purportedly satisfy McNally, and then affirmed on the basis of these theories even though they were not put before the jury." 39 These efforts to "salvage" pre-McNally convictions have been described as "commendable" for "treating technicality with sophistication in the interest of substantial justice."40 By viewing McNally's "property" requirement as an annoying technicality that a healthy dose of legal creativity can cure, however, courts have created ad hoc distinctions, not a principled test for deciding what constitutes mail fraud.

\section{The Peculiar Nature of Licenses}

Cases involving fraudulently obtained licenses, permits, and professional certificates have also fallen victim to the post- $\mathrm{Mc}$ Nally "creative property" phenomenon. The courts are in some disarray as to which side of the "property" line licenses fall.41 There are four basic theories under which courts apply property

38 Ochs, $842 \mathrm{~F} 2 \mathrm{~d}$ at 523.

s9 Id. The idea of "finding" property where it was not thought to exist before is not a new phenomenon. A similar "dephysicalization" of property took place in the nineteenth century, as courts began to recognize business goodwill, trademarks, trade secrets, accession, privacy, and rights in dead bodies as property rights, so as to invoke the jurisdiction of the Chancery courts. See Kenneth J. Vandevelde, The New Property of the Nineteenth Century: The Development of the Modern Concept of Property, 29 Buff L Rev 325, 334-35 (1980).

to Frank, 914 F2d at 835 (Cudahy dissenting).

4 See, for example, Allard, 864 F2d 248 (medical licenses are property); Martinez, 905 F2d at 713-15 (same); Ferrara, 701 F Supp at 42 (contrary); Toulabi, 875 F2d at 125 (taxi licenses are not property); United States v Turoff, 701 F Supp 981, 985 (E D NY 1988) (taxi medallions are property); Frank, 914 F2d at 832-33 (driver's license is property); United States v Kato, 878 F2d 267, 269 (9th Cir 1989) (pilots' licenses are not property); Granberry, 908 F2d at 280 (school bus operator permit is not property); United States $v$ Murphy, 836 F2d 248, 253-54 (6th Cir 1988) (bingo license is not property); United States $v$ Ianniello, 677 F Supp 233, 234-35 (S D NY 1988), aff'd, 894 F2d 1280 (11th Cir 1990) (liquor license is property); United States v Italiano, 701 F Supp 205, 207 (M D Fla 1988) (cable television franchise is property); United States $v$ Slay, 717 F Supp 689, 692 (E D Mo 1989) (an attempt to obtain a cable television franchise is not property); United States $v$ Schwartz, 924 F2d 410, 417-18 (2d Cir 1991), reversing in relevant part, United States $v$ Berg, 710 F Supp 438 (E D NY 1989) (government has no property interest in approving arms export licenses); Medical, Inc. $v$ Angicor Ltd., 677 F Supp 1000, 1005 (D Minn 1988) (FDA's interest in approving exports is not property). 
analysis to licenses under $\S 1341$. Under the first theory, if the license the defendant obtains is properly considered her property, the defendant has committed mail fraud, irrespective of whether the license was the property of the state. The second theory reasons that if the license is property in the hands of the licensee, it must also be property when in the hands of the state. The third theory looks at licenses more as a manifestation of the state's property interest in the right to control its own resources. The fourth theory finds $\S 1341$ violations based on the state's property interest in the physical piece of paper that is the license. This Section exposes the confusion produced by each of these theories.

The first theory proposes that McNally's money or property requirement is satisfied if the defendant obtained for herself money or property, and that a license is such property. ${ }^{42}$ This theory essentially argues, as a matter of statutory construction, that the loss to the victim is not a relevant inquiry under $\S 1341 .^{43}$

Under the second theory, courts have looked to the nature of the victim's loss, but have reached widely differing conclusions. Several circuits have reasoned, for example, that one does not violate the mail fraud statute by fraudulently obtaining a license, because neither blank licenses nor completed and issued licenses are the property of the issuer. The Sixth Circuit first expounded this theory in United States $v$ Murphy, holding that although a bingo license was property of the charitable organization to which it had been issued, neither the unissued nor the issued certificate of registration was the property of the State of Tennessee. ${ }^{44}$

Other courts have decried the Alice in Wonderland absurdity of the proposition that "A has nothing which, when he gives it to B, becomes something." 45 The Third Circuit, for example, has held that licenses are the property of the licensor for purposes of $\S 1341$, explicitly rejecting any theory of "incipient or embryonic property." ${ }^{46}$ The thrust of this criticism of Murphy is that it re-

42 See Martinez, 905 F2d at 713 ( $\$ 1341$ is broad enough to cover a scheme to defraud a victim of something that takes on value only in the hands of the acquirer).

${ }^{4}$ Id (although the court does go on to examine whether the victim had been deprived of property).

"4 836 F2d 248, 253-54 (6th Cir 1988). The court did not elaborate on or cite any precedential authority for this view, nor did it suggest what type of interest, if any, the state did have in those licenses. The Eighth and Ninth Circuits have followed the Murphy reasoning. Granberry, 908 F2d at 280; Kato, 878 F2d at 269.

4s Turoff, $701 \mathrm{~F}$ Supp at 989. See also Berg, $710 \mathrm{~F}$ Supp at 444 ("To hold as some courts have ... that such valuable property vanishes when held in the hands of the issuer strikes the Court as preposterous."), rev'd in relevant part as Schwartz, 924 F2d at 417-18.

‘6 Martinez, 905 F2d at 713. 
sults in simultaneously calling a thing "property" and "not property," depending on who happens to be laying claim to it at the moment. ${ }^{47}$

Under the third theory, some courts have found that the government is interested in licenses and permits as a property holder under a "right to control its resources" theory. These courts have held that the right to control expenditures is intangible property for purposes of $\S 1341,{ }^{48}$ as is the right of "exclusive control over the persons and type of persons with whom it decide[s] to enter employment agreements and contracts." 49 One district court has expanded this theory to include control over the issuance of licenses. In United States $v$ Paccione ${ }^{50}$ a district court held that the government has a property right in control over the distribution of items of value, and that licenses and permits are such items. ${ }^{.1}$ At issue in Paccione was a scheme in which the defendants illegally dumped medical wastes without having obtained the necessary permit. ${ }^{62}$ The court explained that the permit was as much an "item of value" to the government as are government contracts, primarily because the licensing scheme for medical wastes directly implicates and protects the government's money. ${ }^{53}$ The court held that the fraudulent failure to procure such permits deprived the state of control over the expenditure of its money, presumably because the state developed the licensing scheme in order to deny permits to those it deemed likely to saddle it with a costly cleanup

47 See Martinez, $905 \mathrm{~F} 2 \mathrm{~d}$ at 714 (calling Murphy's distinction between issued and unissued licenses "esoteric").

48 Shyres, 898 F2d at 652.

19 Granberry, 908 F2d at 279-80. In Granberry, the defendant had concealed a murder conviction on his application to the state for a school bus operator permit and subsequently obtained employment with a school district. The court upheld five of the six theories of mail fraud against the school district, but rejected all claims of fraud against the state. The rejected allegations included: "control of how its Department of Revenue spends its resources processing school bus operator permit applications," "expenses and costs of processing a fraudulent school bus operator permit application," "the exclusive control of distribution of school bus operator permits," and "the physical piece of paper, namely the School Bus Op. erator permit." Id at 279. See United States v Biaggi, 675 F Supp 790, 801-02 (S D NY 1987) (the right of the Department of Defense to award millions of dollars in government contracts is a property right).

so 738 F Supp 691 (S D NY 1990).

${ }^{51}$ Paccione, 738 F Supp at 702-03, citing Biaggi, 675 F Supp at 801-02.

${ }^{82}$ Id at 700. The prosecution in Paccione alleged that the defendants defrauded the City and State of licensing fees, by failing to obtain and pay for the proper dumping permits. The court equated the failure to obtain a permit with the fraudulent procurement of a permit, implying that both activities constitute mail fraud. Id at 702-03.

${ }^{53}$ Id at 703. 
operation. ${ }^{54}$ Setting aside the peculiar way in which the court applied this reasoning to the facts of the case, Paccione is important for the court's equation of licenses with government contracts and other items of value. Paccione also suggests that licenses are the government's property if one of the government's purposes in initiating a licensing scheme is to avoid future legal liabilities. ${ }^{\mathbf{5 5}}$

In contrast, other courts have concluded that the government is not interested in the license as a property holder. ${ }^{56}$ This line of reasoning picks up on the McNally requirement, noted in a footnote, that when the government is the victim, it must be interested in the property in question as a property holder, not just as a regulator. ${ }^{57}$ The thrust of the argument is that although the license is property from the licensee's perspective, "in the sense that he may not be compelled to surrender the entitlement except on proof of wrongdoing," perspective.

Under the fourth theory, several courts have suggested that the government has a property right in the physical license or permit itself, and that a fraud involving this piece of tangible property violates $\S 1341$. This position emphasizes the state's statutory or common law possessory interests in the licenses it issues, including the right to initiate conversion and larceny actions for the outright theft of those licenses, ${ }^{58}$ and the availability of replevin and damages remedies..$^{60}$ For example, Judge Noonan of the Ninth Circuit

s4 Id at 702. The court distinguished Kato, Toulabi, and Murphy by noting that "none of those licenses or permits implicate(d) the governmental budget, at least in as direct a way as is present in this case." Id at 702-03.

so The Eighth Circuit has rejected a similar argument, however. In Granberry, the court noted that "the school district's desire to avoid tort liability [by adopting a policy of not permitting convicted felons to drive its school buses] does not qualify under the McNallyCarpenter rule. The theory of this allegation twists the word 'property' entirely out of its context." 908 F2d at 280.

so Ferrara, 701 F Supp at 42 (license to practice medicine); Evans, 844 F2d at $40-42$ (government's right to control the foreign resale of arms for which an arms export license had been fraudulently obtained); Medical, Inc., 677 F Supp at 1005 (FDA's interest in approving exports).

${ }^{57}$ McNally, 483 US at $358-59$ n 8.

ss Toulabi, 875 F2d at 125 .

60 Turoff, 701 F Supp at 988 (citing NY Penal Law § 155.00(1) (McKinney 1988), which defines property for purposes of the state larceny statute as "any article, substance or thing of value").

so Evans, 844 F2d at 41 (the court declined to find a property right in part because the government had no remedy of replevin); Turoff, 701 F Supp at 986; Martinez, 905 F2d at 713 (state could replevy, or enjoin the use of, a medical license); Frank, 914 F2d at 833 (state had the right to repossess licenses of drivers convicted of driving under the influence of alcohol). 
has noted that " 'all jurisdictions' recognize that written instruments, such as deeds, can be stolen," and that blank bonds are "securities" under a federal statute forbidding the interstate commerce of stolen securities. ${ }^{\text {11 }}$ In Judge Noonan's view, it is largely irrelevant that the license has "more value when filled in," for "[i]f blank paper can be stolen and transported, is it not property?"62 Likewise, a district court enumerated a number of reasons why it found that the licensing agency had a possessory-and thus a property-interest in taxi medallions: (1) the agency "maintained them under lock and keys in its offices"; (2) the agency had title to them; and (3) "an action for conversion of those medallions would lie and either replevin or damages would be an available and appropriate remedy."Bs

The Second Circuit, however, recently characterized as "patently absurd" the argument that arms export licenses constitute tangible property merely because they have a "physical presence" in the slip of paper, the ink, the seal of the Department of State, and the signature of the licensing officer. ${ }^{64}$ The Ninth Circuit takes a similar stance; while the paper is undoubtedly tangible, the Ninth Circuit has held that "it is simply negligible-de minimis as a matter of law and insignificant as a matter of fact, apart from the legal entitlement it represents."

\section{Interpreting McNally's "Property" Requirement}

Most modern scholars would agree that "the notion of a complete set of timeless, natural, or proper property rules is absurd," because "[p]roperty rights are a cultural creation and a legal conclusion." 67 That is, the more accurate use of the word "property" is

${ }^{81}$ Kato, $878 \mathrm{~F} 2 \mathrm{~d}$ at 271 (Noonan, concurring and dissenting) (citations omitted).

${ }^{62}$ Id. The majority in Kato similarly suggested that "blank sheets of paper" may qualify as property, provided the prosecution alleges such a loss in the indictment. Kato, 878 F2d at 269. The Seventh Circuit has also made this suggestion in Frank, 914 F2d at 833.

${ }^{63}$ Turoff, $701 \mathrm{~F}$ Supp at 986 . The court also found it significant that the defendant could not pass a good title to the medallions to a third person, because the city, not the defendant, was their true owner. Id.

${ }^{64}$ Schwartz, 924 F2d at 417-18.

6s Granberry, 908 F2d at 280. See also Frank, 914 F2d at 835 (Cudahy dissenting) (characterizing the majority's argument based on the state's possessory interest in the physical license as a "'reach' which even the claims of substantial justice cannot possibly justify").

${ }^{8 B}$ C. Edwin Baker, Property and Its Relation to Constitutionally Protected Liberty, 134 U Pa L Rev 741, 743 (1986). See also Charles A. Reich, The New Property After Twenty-Five Years, 24 USF L Rev 223, 230 (1990); Vandevelde, 29 Buff L Rev at 325 (cited in note 39 ).

${ }^{87}$ Baker, $134 \mathrm{U} \mathrm{Pa} \mathrm{L}$ Rev at 744 (cited in note 66). 
to "denote the legal interest (or aggregate of legal relations) appertaining to [a] physical object," What is property to one party may very well not be property to another, depending on what legal interests a party has in the right in question.

One district court has thus complained that the McNally decision prompted an "impetus to return to the arcane learning of the law of property." "B9 Without question, the Court in McNally adopted the "money or property" test without ever defining what it meant by "property."70 At the same time, however, the Court did not at any point indicate that it was applying some novel or revolutionary usage of that term; it certainly never suggested the need to reinvent the "property" wheel. Rather, the Court made the much less ambitious assertion that, however one defines "property," the scheme must have involved it (in a particular way), or else the scheme was not mail fraud. ${ }^{71}$

This Comment thus does not purport to define the term property, preferring to leave that task to the already extensive scholarly debate. ${ }^{72}$ Rather, this Comment analyzes how the Supreme Court used the property requirement in McNally and Carpenter. Specifically, this Section addresses two considerations: whose property and how much of it must be at issue in order to constitute mail fraud. This Section concludes that a cognizable offense under $\S 1341$ requires: (1) that a victim lost or stood to lose a valuable (tangible or intangible) property right; and (2) that the schemer gained or stood to gain a (tangible or intangible) property right. ${ }^{73}$

6s Wesley N. Hohfeld, Some Fundamental Legal Conceptions as Applied in Judicial Reasoning, 23 Yale L J 16, 21 (1913).

69 Turoff, $701 \mathrm{~F}$ Supp at 986.

70 Contrary to two circuits' interpretations, McNally did not suggest that the term "property" be interpreted "liberally." See Evans, 844 F2d at 40 ("the Supreme Court has not directed us to interpret 'property' more broadly than usual"). But see Murphy, 836 F2d at 253; Martinez, 905 F2d at 714 .

${ }^{71}$ This is not meant as applause for the Court's test. In both McNally and Carpenter, the Court used the word "property" as if it had some intrinsic meaning, masking the selfjustifying circularity of both opinions, especially when losses of intangible or prospective entitlements are at issue.

${ }^{2}$ See, for example, Baker, 134 U Pa L Rev 741 (1986) (cited in note 66); Felix S. Cohen, Transcendental Nonsense and the Functional Approach, 35 Colum L Rev 809 (1935); Susan Rose-Ackerman, Inalienability and the Theory of Property Rights, 85 Colum L Rev 931 (1985); John Edward Cribbet, Concepts in Transition: The Search for a New Definition of Property, 1986 U Ill L Rev 1.

${ }^{73}$ Some courts have erroneously attempted to distinguish property rights from property interests, claiming that $\S 1341$ only covers frauds involving the former. See Berg, $710 \mathrm{~F}$ Supp at 437. Given the already heady inquiry of distinguishing intangible rights that are property from intangible rights that are not, it is difficult to see how this second academic 
The gain to the schemer need not bear any relation to the loss to the victim.

\section{A. Whose Property Must Be at Issue?}

A prosecution that relies solely on a theory that the defendant was unjustly enriched by the fraudulent scheme is insufficient to allege a cognizable offense. The mail fraud statute requires a loss ${ }^{74}$ to the victim of the alleged fraud. ${ }^{75} \mathrm{McNally}$ itself compels this answer. The Court noted that the defendant had in fact profited by his scheme, ${ }^{78}$ yet ruled that the scheme was not a cognizable offense under $\S 1341$. Moreover, the Court's holding that "§ 1341 [is] limited in scope to the protection of property rights"77 suggests that $\$ 1341$ protects victims from losing, not that it prohibits swindlers from profiting.

While a loss to the victim is necessary, however, it does not appear to be sufficient. Rather, a showing of gain to the schemer may also be necessary. ${ }^{78}$ The history of the mail fraud statute suggests that "Congress almost surely contemplated a classic fraud in which the victim is induced by false representations to hand over money or intangible property to the defendant and the victim's loss is the defendant's gain."" "Classic" mail fraud thus required a symmetry between losses and gains. After Carpenter, however, this symmetry is no longer required; the victim's loss need not be equivalent to the schemer's gain. After all, in Carpenter, the victim lost confidential business information, while the defendant gained insider trading profits from trading on that information. Under the narrow, symmetrical view, Carpenter would not have been a cognizable case of mail fraud. ${ }^{80}$ Thus, McNally is satisfied if the victim

exercise clarifies or focuses the problem. Moreover, $\S 1341$ does not call for such an exercise. Carpenter refers to property interests as well as rights. 484 US at 25.

74 A potential loss also counts, as discussed in note 90.

${ }^{76}$ See Evans, 844 F2d at 39 (citation omitted). See also United States $v$ Starr, 816 F2d 94, 101 (2d Cir 1987); United States v Sanders, 696 F Supp 327, 329 (N D Ill 1988); Reitman $v$ New York City Transit Authority, 704 F Supp 346, 348 (E D NY 1989); Ferrara, 701 F Supp at 42 .

${ }^{76}$ McNally, 483 US at 360.

77 Id.

78 The lack of clarity on this issue existed well before the McNally decision. See Craig M. Bradley, Foreword: Mail Fraud After McNally and Carpenter: The Essence of Fraud, 79 J Crim L \& Criminol 573, 593 (1988).

${ }^{79}$ Id at 594 (citation omited).

so See id at 594-95 n 139 ("The government could not have argued in Carpenter that [the defendant's] gain was simply the confidential information. He already had that information as part of his job. It was the trading on the information that was the fraud." (em. 
lost something of relatively small value $e^{81}$ that took on great value in the hands of the defendant. ${ }^{82}$ The Third Circuit's assertion in Martinez, however, that "the statute . . . is broad enough to cover a scheme to defraud a victim of something that takes on value only in the hands of the acquirer"83 does not satisfy McNally.

\section{B. How Much Property Must Be at Issue?}

As several circuits have recognized, not every scheme in which the victim loses a trivial bit of property constitutes the federal offense of mail fraud. Rather, a "materiality" threshold-although not explicit-is inherent in the mail fraud statute. ${ }^{84}$ Even when the mail fraud statute had its greatest reach-in pre-McNally "intangible rights" cases-the courts generally agreed that a breach of fiduciary duty by itself was not enough to establish mail fraud. ${ }^{85}$ Instead, in a case involving an employee's duty to disclose information to the employer, one court noted that material information is information that the "employee has reason to believe ... would lead a reasonable employer to change its business conduct." 86 Another circuit characterized the materiality requirement in the employment context as an activity that carries "a significant risk of identifiable harm to the employer." 87 The Court's recognition in McNally that victims, and not the mails, were afforded protection by the mail fraud statute ${ }^{88}$ strengthens the case for requiring a cer-

phasis in original)). The Second Circuit has recognized this principle in dicta. Evans, 844 F2d at 39-40.

${ }^{81}$ But not so small as to be de minimis. See Section II.B.

82 This primary focus on the victim's loss, with only a secondary focus on the defendant's gain, comports well with the legislative history of the mail fraud statute and its predecessors, which suggests that "the original impetus behind the mail fraud statute was to protect the people from schemes to deprive them of their money or property." McNally, 483 US at 356. Note, however, that an alternative theory suggests that "[i]t was the forbidden 'abuse' of the mails that was the gist of the crime, and not the scheme to defraud that it effectuated." See Rakoff, 18 Duquesne L Rev at 790-95 (cited in note 4). Under this theory, it is largely irrelevant whether anyone lost or gained anything as a result of the fraud. However, the Court in McNally explicitly adopted the former theory. McNally, 483 US at 356.

${ }^{83}$ Martinez, 905 F2d at 713 (emphasis added).

s4 See United States v Daily, 921 F2d 994, 1007 (10th Cir 1990) (noting that although materiality is not a "separate essential element" of wire fraud, "there is a materiality aspect to the determination whether the acts of an accused give rise to a scheme to defraud").

ss United States v Ballard, 663 F2d 534, 540 (5th Cir 1981) (citation omitted). See United States v Feldman, 711 F2d 758, 765 (7th Cir 1983). See also Bradley, 79 J Crim L \& Criminol at 599 n 165 (cited in note 78) (noting that failure of an employee to disclose the pilfering of office supplies taken in violation of company policy would not be mail fraud under the intangible rights doctrine).

${ }^{86}$ Ballard, 663 F2d at 541.

87 United States v Lemire, 720 F2d 1327, 1337 (DC Cir 1983).

${ }^{8 s}$ See note 82. 
tain level of materiality before the fraud rises to the level of a $\S$ 1341 offense. Specifically, the Court cited language from one of its earlier decisions holding that "to defraud" "usually signifies the deprivation of something of value by trick, deceit, chicane or overreaching." contains an implicit materiality requirement: "To defraud' mean[s] depriving individuals or the government of something of value." $" 90$

The Court in McNally made clear its intent to check the expansion of the mail fraud statute by narrowing the types of activities which $\S 1341$ covers. It is likely the Court would look with approval on the materiality threshold as yet another way in which it limited the scope of $\S 1341$ in McNally, albeit only implicitly. This Comment argues that "value" means "material value."

\section{Applying the Proposed Framework to Cases of Fraudulently Obtained Licenses}

After $M c N a l l y$, a mail fraud violation requires that the victim was defrauded of money or valuable property, and that the schemer gained money or property. This Section applies that framework to fraudulently obtained licenses. By looking to other contexts in which courts have defined property to include licenses, the Section concludes that licenses are property in the hands of the defendant-licensee for purposes of $\S 1341$. The Section also demonstrates, however, that licenses are not the valuable property of the state-licensor. The discussion begins by pointing out that the major arguments attempting to characterize licenses as the state's property-possessory interests and rights to enjoin use-are

39 McNally, 483 US at 358, citing Hammerschmidt $v$ United States, 265 US 182 (1924) (emphasis added).

so Schwartz, 924 F2d at 418. Note that the materiality requirement does not require that the victim has actually suffered a loss. The fraud may remain inchoate. See United States v Stewart, 872 F2d 957, 960 (10th Cir 1989); Schreiber Distributing Co. v Serv-Well Furniture Company, Inc., 806 F2d 1393, 1400 (9th Cir 1986). The mail fraud statute requires only that the fraudulent scheme carried with it the potential for loss of a magnitude sufficient to cross the materiality threshold. McNally did not change this concept. See Schwartz, 924 F2d at 420 ("It need not be shown that the intended victim of the fraud was actually harmed; it is enough to show defendants contemplated doing actual harm .....").

The need to recognize and enforce the materiality requirement is all the more compelling due to the fact that mail and wire fraud violations are predicate acts for the Racketeer Influenced and Corrupt Organizations Act (RICO). See 18 USC § 1961(1) (1988). See also Sedima, 473 US at 501 (Marshall dissenting) ("The single most significant reason for the expansive use of civil RICO has been the presence in the statute, as predicate acts, of mail and wire fraud violations."). 
insufficient to show that the state is "holding" (and not merely regulating) property. Nor is one the least bit compelled to conclude that private property necessarily had its origins as property "held by" the state. Rather, the Section concludes by describing how licensing schemes are classic examples of government's use of its police power to regulate conduct.

\section{A. Licenses as Property of the Licensee}

The prosecution can easily demonstrate that licenses are property of the defendant-licensee, given that courts recognize in a wide variety of contexts that licensees' legal interests in a license rise to the level of a property right. First, courts have widely acknowledged that "licensees have a [constitutionally] protected property interest and therefore cannot be deprived of a license absent due process of the law." In large part, this constitutional protection stems from a recognition that taking away a person's license is often tantamount to taking away that person's livelihood. ${ }^{92}$ Second, courts have also begun including the value of professional licenses as marital property in divorce cases. ${ }^{93}$ Third, courts have treated various licenses as property of a bankrupt's estate for purposes of distributing assets to creditors. For example, courts have held that broadcasting licenses obtained from the Federal Communications Commission are the property of the bankrupt's estate, ${ }^{94}$ as are airplane "landing slots" obtained from the Federal Aviation Administration, ${ }^{95}$ certificates of public convenience and necessity, ${ }^{96}$ and liquor licenses. ${ }^{97}$ Similarly, unless a state licensing scheme expressly prohibits the taking of security in-

91 Martinez, 905 F2d at 713 (citations omitted). See also Bell v Burson, 402 US 535, 542 (1971) (driver's license); Barry v Barchi, 443 US 55, 63-64 (1979) (horse trainer's license); Willner $v$ Committee on Character and Fitness, 373 US 96, 102 (1963) (admission to the bar).

92 See Martinez, 905 F2d at 713 (citation omitted).

93 O'Brien v O'Brien, 66 NY2d 576, 498 NYS2d 743, 489 NE2d 712, 717 (1985).

* In re Smith, 94 Bankr 220, 221 (Bankr M D Ga 1988); Matter of Fugazy Express, Inc., 114 Bankr 865, 869 (Bankr S D NY 1990). But see In re Overmyer Telecasting Co., 35 Bankr 400, 401 (Bankr N D Ohio 1983); In re Oklahoma City Broadcasting Co., 112 Bankr 425, 429 (Bankr W D Okla 1990).

${ }^{3}$ American Central Airlines, Inc. v O'Hare Regional Carrier Scheduling Committee, 52 Bankr 567 (Bankr N D Iowa 1985); In re McClain Airlines, Inc., 80 Bankr 175, 177-79 (Bankr D Ariz 1987). But see In re Braniff Airways, 700 F2d 935, 942 (5th Cir 1983); Air Illinois, Inc. v Federal Aviation Administration, 53 Bankr 1, 2 (Bankr S D Ill 1985).

'o In re Rainbo Express, Inc., 179 F2d 1, 5 (7th Cir 1950); In re Rocky Mountain Trucking Co., Inc., 47 Bankr 1020, 1021 (Bankr D Colo 1985).

${ }^{97}$ In re Miller, 68 Bankr 385, 387 (Bankr W D Pa 1986). 
terests in certain licenses, courts tend to uphold a creditor's security interest in that license..$^{98}$

One can attribute much of the judicial recognition of licenses as property of the licensee to the influence of Professor Charles Reich's seminal article, The New Property. ${ }^{99}$ Reich defines "new property" as various forms of government largess, including licenses, which fall outside the traditional definition of property, and argues that largess should begin to do the work of property: "As we move toward a welfare state, largess will be an ever more important form of wealth. And largess is a vital link in the relationship between the government and private sides of society. It is necessary, then, that largess begin to do the work of property."

\section{B. Licenses as Property of the Licensor}

Given that determining loss to a victim is a required inquiry in $\S 1341$ cases, it is important first to identify that victim. In most cases, the prosecution alleges that the licensing body (usually a governmental unit or agency) was the victim of the fraud. ${ }^{101}$ This Comment argues that while the licensor is clearly regulating the

${ }^{86}$ In re O'Neill's Shannon Village, 750 F2d 679, 682-83 (8th Cir 1984) (noting the "commercial reality" that a liquor license is frequently the bar's most valuable asset, and also the UCC's broad definition of property to which a security interest may be attached). Likewise, even where the state licensing scheme expressly provides that the license is not property of the licensee, courts have held that the license has sufficient indicia of property under federal law so as to be subject to federal tax liens. Baltimore-55, Inc. $v$ Pennsylvania, 1985 WL 6046 (M D Pa); United States $v$ Wingfield, 822 F2d 1466 (10th Cir 1987); Aqua Bar \& Lounge, Inc. v United States Department of Treasury, 539 F2d 935 (3d Cir 1976).

${ }^{90}$ Charles A. Reich, The New Property, 73 Yale L J 733 (1964). See 24 USF L Rev (1990), a special issue devoted to the contributions Reich's article has made to the advancement of legal thought.

100 Reich, 73 Yale L J at 778 (cited in note 99). In addition to licenses, Reich also counts franchises, social security benefits, unemployment compensation, state and local welfare, government jobs, government contracts, business subsidies, public resources, and government services among the "new property." Id at 733-37.

${ }^{101}$ The victims of a fraudulent licensure scheme are not limited to the licensing body, however. First, a few courts have accepted the theory that employers misled by the defendant had been defrauded of money or property. See, for example, Allard, 864 F2d at 251 (defendant fraudulently procured a medical license from the Commonwealth, and subsequently secured an internship at a hospital); and Granberry, 908 F2d at 279-80 (bus driver who had fraudulently obtained a permit from the state defrauded employer out of wages). Second, it is conceivable that in cases of licenses issued in limited quantities, such as taxi licenses and liquor licenses, the applicant who was the one hundred first person in line for one hundred licenses was the true victim of the defendant's fraud. However, courts have generally held (in other contexts) that, while a licensee may have a property interest in her license, an applicant does not have a property interest in the issuance of such a license. Scott $v$ Village of Kewaskum, 786 F2d 338, 339 (7th Cir 1986) (citation omitted). See also Polenz v Parrott, 883 F2d 551, 555-56 (7th Cir 1989). 
distribution of property, it is acting as a property holder only in an inconsequential sense.

That the government acts as a regulator when it issues licenses and permits is beyond dispute. Licensing schemes are generally regulatory in nature, ${ }^{102}$ arising from the state's constitutional and statutory police power. ${ }^{103}$ As the following subsections demonstrate, however, the arguments that suggest that the government is also acting as a property holder are invalid.

\section{Possessory interests.}

Several courts have expressly or impliedly relied on the government's possessory interest in the license in holding that such licenses are the state's property. ${ }^{104}$ The most that this reliance on possessory interests can accomplish, however, is to establish the licensor's property interest in the physical license itself-the ink, the paper, and the seal. The value of the physical license, however, is so negligible that it does not rise to the level of "materiality" under $\S 1341 .{ }^{105}$

Nor is the "chose in action" theory a sustainable one. Some courts have reasoned that, by virtue of the fraudulent scheme, the defendant attempted to deprive the government of its legal right of action for repossession. ${ }^{108}$ However, the defendant does not deprive the issuer of its right of action for repossession when she fraudulently obtains a license. At most, the applicant makes it more difficult for the government to know when to exercise its right of repossession. ${ }^{107}$

One can imagine limited circumstances, however, in which the government's possessory interests may rise to the level of a property right. In Frank $v$ United States, ${ }^{108}$ an attorney had been con-

\footnotetext{
${ }^{102}$ Some licenses, however, may be "non-regulatory" or "revenue-producing." Revenue licensing schemes generally attach no real conditions beyond payment of the license fee, and have as their main object the raising of revenue for the state's coffers. Malcolm B. Parsons, The Use of the Licensing Power by the City of Chicago 38-39 (Illinois, 1952) (providing examples such as the licensing of dogs, currency exchanges, furniture movers, and amusements).

${ }^{103}$ Gundling $v$ City of Chicago, 177 US 183, 188 (1900) ("Regulations respecting the pursuit of a lawful trade or business ... are questions for the State to determine, and their determination comes within the proper exercise of the police power.").

${ }^{104}$ Turoff, 701 F Supp at 986; Evans, 844 F2d at 40-42; Kato, 878 F2d at 271; Frank, 914 F2d at 832-33. See Section I.D.

${ }^{105}$ Schwartz, 924 F2d at 418 (citation omitted).

${ }^{108}$ Berg, 710 F Supp at 444-45, rev'd in relevant part as Schwartz, 924 F2d at 416-18.

${ }^{107}$ Moreover, note that in Berg, the government actually did "fully avail[] itself of that right by ultimately seizing both shipments for which false licenses had been obtained." Schwartz, 924 F2d at 418.

108914 F2d 828, 829 (7th Cir 1990).
} 
victed (pre-McNally) of mail fraud for a scheme in which he prevented his clients" "driving under the influence of alcohol" (DUI) convictions from appearing in the State's records. As part of the scheme, the defendant surreptitiously arranged with a court bailiff for a client's driver's license to be returned to the client, with the result that the State's Bureau of Motor Vehicles (BMV) never received the surrendered license. Though calling it "a close question,"109 a divided panel of the Seventh Circuit upheld the mail fraud conviction. The court emphasized that state law provided that "the surrendered license itself is part of the court record and is [thus] tangible property of the BMV."110

\section{Rights to enjoin use.}

The availability of an injunctive right or the right to repossess a license does not mean that the license is property. Some courts have attempted, however, to root the government's property interest in a license in the right to enjoin the unauthorized use of that license, or alternatively, to seize and repossess the license. ${ }^{111}$ Courts have largely based this reasoning on language in Carpenter, in which the Court pointed to the availability of injunctive relief in determining that the misappropriated confidential business information constituted property.12 This argument, however, mischaracterizes Carpenter's reference to injunctive rights. Specifically, the Court in Carpenter noted that confidential information compiled by a corporation in the course of its business "is a species of property to which the corporation has the exclusive right and benefit, and which a court of equity will protect through the injunctive process or other appropriate remedy."113

This passage illustrates not only that business information is the confidential property of the business, but also that it happens to be a particular type of property, the use of which by others may

109 Id at 833.

110 Id. The court seemed to assume that had the defendant surreptitiously arranged with the bailiff for the return of the hearing abstract or other court documentation, he would have defrauded the state of its property. The dissent argued that the license (as a court record) was "merely a device for facilitating the flow of information to the State" and that the right to such information is not a property right. Id at 835 (Cudahy dissenting). However, this argument seems to collapse under its own weight. See Carpenter, 484 US 19 (information which had independent economic value was "property"). Judge Cudahy dismissed Carpenter with a "cf."

111 Turoff, 701 F Supp at 988; Frank, 914 F2d at 832-33.

112 Carpenter, 484 US at 26.

113 Id (citation omitted). 
appropriately be enjoined. The Court is not saying the converse, however: that the availability of injunctive relief indicates the presence of a property right.

The right to injunctive relief is not exclusive to the protection of property rights; injunctive rights can and do serve purely regulatory purposes. In another context, courts have held that the following types of injunctions had been granted to enforce regulations rather than to protect property: ${ }^{114}$ injunctions against engaging in commodities futures trading; ${ }^{115}$ a restraining order prohibiting a debtor from withholding payment of back wages allegedly due under the Fair Labor Standards Act; ${ }^{116}$ a state's cease and desist order prohibiting a company from operating as a result of noncompliance with certain pollution control regulations; ${ }^{117}$ and an injunction prohibiting the operation of a discotheque without having received the proper permit, on the ground that it violated town zoning and land use regulations. ${ }^{118}$ In short, although a salient feature of what it means to hold property is that one may enjoin the use of that property by others, ${ }^{110}$ the availability of a right of injunction does not compel one to conclude that a property right is at stake. As is illustrated above, rights of injunction are often available to enforce the state's rights as a regulator.

3. Distinguishing between "holding" and "regulating" property.

Several courts have cited Professor Reich as authority for the position that licenses and other forms of "new property" were originally public property. These courts regard the view that licenses are only property in the hands of the licensee, but never in the hands of the government, as an "inversion of historical fact."120 Professor Reich himself suggested this argument, by comparing licenses and other forms of government largess to traditional prop-

114 Injunctive proceedings brought by governmental units to enforce police or regulatory powers are exempt from the automatic stay provisions of the Bankruptcy Code. 11 USC $\S 362(\mathrm{~b})(4)$ (1988).

${ }^{215}$ Commodities Futures Trading Commission v Incomco, Inc., 649 F2d 128, 131-34 (2d Cir 1981).

${ }^{116}$ Marshall v Int'l FormalWear, Inc., 6 BCD 477 (Bankr S D Ga 1980).

${ }_{117}$ Matter of Canarico Quarries, Inc., 466 F Supp 1333, 1334-35 (D Puerto Rico 1979). See Department of Environmental Resources v Peggs Run Coal Co., $55 \mathrm{~Pa}$ Commw 312, 423 A2d 765 (1980).

118 In re Cousins Restaurants, Inc., 11 Bankr 521, 521-22 (Bankr W D NY 1981).

110 See Carol Rose, The Comedy of the Commons: Custom, Commerce, and Inherently Public Property, 53 U Chi L Rev 711 (1986).

${ }^{120}$ Turoff, $701 \mathrm{~F}$ Supp at $989-90$ (criticizing Murphy and Ferrara). 
erty and noting that traditional property "comes from the State."121

However, the fact that an individual's private property "originated in" or "came from" the government in no way compels the conclusion that it was originally government property. Instead, it is the state's regulatory authority or police power that often "evolves" over time to become privately held property. ${ }^{122}$

Moreover, the government's regulatory interest in a license does not endow it with a property right in that license. That is, the mere issuance of a document designed to formalize the government's regulation does not thereby create a property right for the government." 123 The Second Circuit has correctly noted that the government may control the private use of private property either through the use of licenses or blanket rules, the license being "nothing more than a formal embodiment of 'the necessary government approval." "124 As such, the paper licenses are merely the state's "regulatory imprimatur," and have no other effect as "property" beyond the representation of this regulatory grant. ${ }^{125}$ Moreover, the language in McNally removing regulatory interests from the ambit of $\S 1341^{128}$ does not distinguish between those regula-

121 Reich, 73 Yale L J at 778 (cited in note 99). Specifically, Reich noted that land, water, minerals, timber, and other natural resources passed into private ownership through grants from the sovereign. He also characterized personal property as owing "its origins and continuance" to the state. Id. However, given Reich's concern-the loss of individual liberty in the modern state-much of the scholarly analysis and judicial recognition of "new property" has centered on the individual recipient, not the dispenser, of the largess. Reich's theory is thus largely irrelevant to the specific issue raised by $\S 1341$ : whether a license is the property of the licensor.

222 Consider the following description, for example: (1) demands for use of a (usually limited) resource grow large enough to create a congestion problem; (2) the state establishes a permit system to regulate use of the resource; (3) permit holders achieve the rights to alienate the permits; and finally, (4) the state regulatory agency formally transfers use rights to the private user and ceases to regulate. Robert $\mathrm{H}$. Nelson, Private Rights to Government Action: How Modern Property Rights Evolve, 1986 U Ill L Rev 361, 374. See also Comment, Retail Liquor Licenses and Due Process: The Creation of Property Through Regulation, 32 Emory L J 1199 (1983), in which the author lists three different types of regulatory schemes regarding the sale of alcohol and examines how "property-like" the liquor licenses are to the recipient under each licensing regime.

${ }_{123}$ Schwartz, 924 F2d at 417-18.

124 Id at 417.

125 Id at 418. In essence, this "de minimis exception" correctly discriminates between the valuable underlying right or privilege conferred by the issuing agent and the physical "certificate of license" (of negligible value at best) embodying that right. See Hohfeld, 23 Yale L J at 21 (cited in note 68) (cited with approval in Schwartz, 942 F2d at 418). The court in Schwartz undoubtedly and correctly rejected the lower court's assertion that "[d]ifferentiating between the license itself and an underlying privilege or property right does not advance the analysis." Berg, $710 \mathrm{~F}$ Supp at $437 \mathrm{n} 1$.

${ }^{126}$ See note 16. 
tory schemes involving formal licensing documents and those that do not. Rather, the Court swept all such regulatory schemes outside the scope of the mail fraud statute.

Arguing that if a license is property of the licensee it must also be property of the licensor (to avoid an Alice in Wonderland absurdity), the Turoff court erred in its basic premise. That court noted that any other result would erroneously equate the sovereign with an individual or a corporation:

It is only through the exercise of [its police powers and taxing powers] that the sovereign obtains the revenues which enable it to function at all and acquire, if it chooses, "property" in the traditional sense. To rob the sovereign of the due exercise of that power by schemes or artifices to defraud, is to rob it of "property" as much as the goods or chattels or money obtained from a private person by similar schemes or artifices. ${ }^{127}$

The fundamental problem with this argument is that, while professing not to equate a state with a corporation, it does precisely that. By comparing fraud in the procurement of licenses with schemes to rob a private person of "goods or chattels or money," the court ignores a basic mark of distinction between the state and the private person, essentially making everything the government touches or uses or regulates "property."128 It is true that both the corporation and the sovereign may own property, lend money, and enter into contracts, but only the state possesses the police power that permits it to regulate activity within its jurisdiction and to subject individual rights to this police power. ${ }^{128}$

The Supreme Court recognized early in this century that "[the] right to pursue any trade or calling is subordinate to the right of the state to limit such freedom of action by salutary regulation where the public health, safety, or welfare of society may

${ }^{227}$ Turoff, $701 \mathrm{~F}$ Supp at 989. See also Paccione, $738 \mathrm{~F}$ Supp at 702-03 (equating licenses with government contracts).

${ }^{128}$ In The Licenses Cases, 46 US 504, 582 (1847), Chief Justice Taney had made a similar assertion: "[The state's police powers] are nothing more or less than the powers of government inherent in every sovereignty to the extent of its dominions." However, Taney's formulation has been soundly criticized on grounds similar to those developed here. See Harry N. Scheiber, Public Rights and the Role of Law in American Legal History, $72 \mathrm{Cal} \mathrm{L}$ Rev 217, 221-22 (1984). See also Rose, 53 U Chi L Rev at 773 (cited in note 119) (noting that "nineteenth century jurists had a propensity to slide easily between police power and public property terminology").

${ }^{220}$ The state, in turn, may delegate portions of its licensing power to municipalities. Sedalia v Standard Oil Co., 66 F2d 757 (8th Cir 1933). Conversely, municipalities have no inherent power to license absent an express delegation of such power by the state. Anchorage v Brady's Floor Covering, 105 F Supp 717 (D Alaska 1952). 
require."130 In fact, the state could-in a valid exercise of police power-prohibit or curtail the pursuit of the trade or calling should the public health, safety, or welfare of society so require. As the Court recognized in Nebbia v New York, "the constitution does not guarantee the unrestricted privilege to engage in a business or to conduct it as one pleases. Certain kinds of business may be prohibited; and the right to conduct a business, or to pursue a calling, may be conditioned."131 Licensure requirements are but one vivid example of how states pass "salutary regulation" in exercise of their police powers to so protect the public health, safety, and welfare. ${ }^{132}$

Importantly, the sovereign's police and regulatory power is separate and distinct from its power as a property holder, making the distribution of taxi or liquor licenses fundamentally different than the distribution of Defense Department contracts, ${ }^{133}$ government jobs, ${ }^{134}$ or even government franchises. ${ }^{135}$ In the former situations, the government is regulating, in the latter, the government is acting as a property holder much as a corporation might.

An applicant who forges her medical school transcript in order to obtain a physician's license, or who lies about a prior conviction in order to obtain a bingo license, or who misrepresents the owner-

130 Scully v Hallihan, 365 Ill 185, 6 NE2d 176, 180 (1936), citing Nebbia v New York, 291 US 502 (1934).

${ }^{231} 291$ US at 527-28 (citation omitted).

${ }_{132}$ Douglas A. Wallace, Occupational Licensing and Certification: Remedies for Denial, 14 Wm \& Mary L Rev 46, 46 (1972) ("In the past three to four decades, occupational licensing has become one of the most pervasive forms of state regulation in the economy.").

${ }^{133}$ Under this reasoning, then, Biaggi, 675 F Supp 790, was correctly decided. In Biaggi, the defendants were convicted of mail fraud for misrepresenting a defense contracting firm as being eligible for minority preferences, and thus defrauding the government of Defense Department contracts.

${ }^{134}$ See, for example, Granberry, 908 F2d at 278 (defendant convicted for fraudulently obtaining job with a school district); see generally note 101. But see United States $v$ Local 359, 889 F2d 1232, 1234 (2d Cir 1989) (court notes in dicta that an attempt to obtain a job for another person with a private company does not constitute wire fraud).

${ }^{135}$ The distinction between franchises and licenses is a slippery one. See Eugene McQullin, The Law of Municipal Corporations $\S 34.03$ at 11 (Callaghan, 3d ed 1986) ("[A]lthough a privilege may constitute a franchise, a privilege is not necessarily a franchise.") (citations omitted). Franchises (which typically encompass such activities as telephone companies, waterworks, electric generating plants and cable television stations), id at $\S 34.08,29-30$, however, generally involve contractual relations in which the government is acting in a proprietary capacity, not a regulatory one. That is, the government is granting to a private actor the right to use inherently "public" property or resources. See generally Rose, 53 U Chi L Rev 711 (cited in note 119). See also United States v Italiano, 701 F Supp 205, 207 (M D Fla 1988), in which the court held that fraudulently obtaining a cable television franchise was mail fraud; United States v Slay, 717 F Supp 689, 693 (E D Mo 1989) (reaching same conclusion in dicta). 
ship of an establishment to obtain a liquor license through a minority set-aside program, deprives the state of its regulatory right to issue licenses to those whom it deems qualified. However, in none of these cases does the applicant defraud the state of a valuable property right. Practicing medicine, running bingo games, and operating liquor stores are "not [activities] made possible by dint of the [state's] resources; [they] are something the applicant can do without the [state's] assistance, and the license simply signifies that the [state] will not hinder or penalize one who pursues this line of work." 136 In each of these cases, the licensor is not interested in the licenses it issues as a property holder, but only as a regulator.

\section{CoNCLUSION}

The Supreme Court dramatically tightened the reins on the mail fraud statute in McNally, and Congress has not loosened them enough to make such activities federal crimes. This Comment criticizes courts' ad hoc approach in creatively "finding" property in challenges of pre-McNally convictions, and illustrates how the outcomes serve little more than the moment.

Based on the appropriate framework for approaching $M c$ Nally's "property" requirement, this Comment concludes that licenses fall outside of that framework. When an applicant fraudulently procures a license, permit, or professional certificate from the state, he almost certainly makes the state's exercise of its regulatory power more difficult. McNally expressly notes, however, that a regulatory interest alone is not a legal interest sufficient to be termed a property right for purposes of $\S 1341$. Nor do the other legal interests and relations cited by some courts, such as the right to possess, repossess, or enjoin use, call into existence a property right. The applicant has simply not defrauded the state of valuable property and has thus not committed the federal offense of mail fraud. 
. 